Vol.3, No.1, Januari 2020, pp.137-147

\title{
Penerapan Data Mining Untuk Memprediksi Pertumbuhan Jumlah Penderita Human Immunodeficiency Virus (HIV) Menggunakan Metode Multiple Linier Regression (Studi Kasus Dinas Kesehatan Provinsi Sumatera Utara)
}

\author{
Muhammad Zunaidi ${ }^{1}$, Asyahri Hadi Nasyuha ${ }^{2}$, Sinta Mega Sinaga ${ }^{3}$ \\ Program Studi Sistem Informasi,STMIK Triguna Dharma \\ Email : 1abi.azhura@gmail.com, 2ayi.nasyuha@gmail.com, 33intamega456@gmail.com
}

\begin{abstract}
Abstrak
Human Immunodeficiency (HIV) virus adalah sebuah virus yang mengakibatkan sebuah penyakit yang tidak dapat disembuhkan bernama AIDS. Berdasarkan profil kesehatan provinsi sumatera utara tahun 2017, pertumbuhan jumlah penderita HIV mengalami peningkatan yang pesat sejak tahun 2013 menandakan bahwa penanganan yang disediakan belum bisa menjangkau keseluruhan penderita HIV yang ada.Perancangan sebuah sistem berbasis dekstop yang mampu menerapkan metode multiple linier regession diharapkan dapat membantu dalam memprediksi pertumbuhan jumlah penderita HIV. Hasil prediksi pertumbuhan jumlah penderita HIV setiap bulannya dapat dijadikan sebagai acuan dalam menyediakan penanganan-penanganan terkait kasus HIV/AIDS
\end{abstract}

Keyword: Data Mining, HIV, Multiple Linier Regression, Regresi Linier Berganda.

\begin{abstract}
The Human Immunodeficiency Virus (HIV) is a virus that causes disease that cannot be called AIDS. Based on the health profile of North Sumatra Province in 2017, the increasing number of people with HIV has increased since 2013 indicating that the development provided cannot reach the total number of HIV sufferers. Desktop-based system design that requires various regression methods is expected to help predict the growth of HIV sufferers. The results of the estimated number of HIV sufferers each month can be targeted in the provision of treatment related to HIV / AIDS
\end{abstract}

Keywords: Data Mining, HIV, Multiple Linear Regression, Multiple Linear Regression.

\section{Pendahuluan}

Acquired Immuno Deficiency Syndrome (AIDS) adalah penyakit-penyakit yang muncul akibat menurunnya kinerja dari sistem kekebalan tubuh yang disebabkan oleh sebuah virus yang sifatnya menular dinamakan dengan Human Immunodeficiency Virus (HIV). Pertumbuhan jumlah penderita HIV setiap tahunnya bisa meningkat bisa menurun. Menurut Marlinda dan Azinar [1] "Indonesia merupakan salah satu negara dengan penambahan kasus HIV/AIDS tercepat di Asia Tenggara, dengan estimasi peningkatan angka kejadian infeksi HIV lebih dari 36\%". 
Pertumbuhan jumlah penderita HIV yang semakin meningkat, maka semakin meningkat pula Angka Kematian akibat AIDS. Dikarenakan ketika seseorang terinfeksi HIV sudah pasti terinfeksi penyakit AIDS juga dan penyakit ini merupakan penyakit yang tidak dapat disembuhkan. Berdasarkan Profil Kesehatan Provinsi Sumatera Utara tahun 2017 [2], pertumbuhan jumlah penderita HIV di Provinsi Sumatera Utara setiap tahunnya sejak tahun 2013 semakin meningkat dengan pesat, menandakan bahwa penanganan-penanganan yang disediakan masih belum sesuai dengan banyaknya jumlah penderita HIV yang ada.

Oleh karena itu penerapan Data Mining dengan Metode Multiple Linier Regression digunakan untuk membantu memprediksi pertumbuhan jumlah penderita HIV, agar persediaan penanganan yang diperlukan bisa disesuaikan dengan jumlah penderita HIV yang ada.

\section{Tinjauan Literatur}

\subsection{Data Mining}

Data Mining secara bahasa dapat diartikan sebagai penambangan data, sebagaimana yang diungkapkan oleh Larose dalam Yasmiati [3] )'Gabungan beberapa cabang kecerdasan buatan seperti statistika dan mesin pembelajar termasuk kedalam salah satu metode analisis data yang disebut dengan penambangan data'.

Menurut Zulham dan Nasyuha [4] "Untuk memperoleh hasil yang lebih dipercaya maka dalam data mining digunakan data yang besar". Dengan kata lain, data mining merupakan suatu bidang ilmu yang mempelajari bagaimana mengelola data yang besar agar dapat menjadi sebuah pengetahuan. berikut:

Pekerjaan dalam data mining terbagi menjadi empat, menurut Prasetyo [5] adalah sebagai

1. Model Prediksi

Model prediksi terbagi menjadi 2 yaitu model klasifikasi dan regresi. Model klasifikasi adalah model yang membedakan data kedalam kelas-kelas dengan tujuan untuk dapat mencari nilai-nilai duga kelas dari suatu objek yang belum diketahui nilai pastinya.

Sedangkan regresi adalah sebuah model yang membutuhkan data dari waktu ke waktu untuk memperkirakan nilai akhir. Analisis Kelompok.

Analisis kelompok atau disebut juga dengan clustering, yaitu membagi suatu data yang besar kedalam kelompok-kelompok tertentu sesuai dengan kesamaan yang terdapat dalam data tersebut.

2. Analisis Asosiasi

Analisis Asosiasi merupakan sebuah analisis yang digunakan untuk mencari pola yang menggambarkan hubungan fitur dalam data.

3. Deteksi Anomali

Merupakan proses yang berkaitan dengan pengamatan sebuah data dari se--jumlah data yang besar. Dicari data yang memiliki perbedaan mencolok dari data lainnya dan disebut dengan outlier.

\subsection{Metode Multiple Linier Regression}

Analisis Regresi adalah salah satu teknik analisis yang dipergunakan untuk mencari hubungan dari dua atau lebih variabel yang bersifat sebab akibat.

Menurut Amrin [6] "Metode Multiple Linier Regression atau Regresi Linier Berganda adalah metode yang digunakan untuk mencari pengaruh dua atau lebih variabel bebas $(\mathrm{X} 1, \mathrm{X} 2, \ldots \mathrm{Xn})$ terhadap variabel terikat(Y)".

Langkah-langkah dari penerapan metode regresi linier berganda adalah sebagai berikut :

J-SISKO TECH Vol. 3, No. 1, $2020: 137-147$ 
1. Mempersiapkan data yang diperlukan dan sudah dikelompokkan dalam kelas-kelas tertentu.

2. Menentukan variabel bebas atau variabel penyebab $(\mathrm{X} 1, \mathrm{X} 2, . . \mathrm{Xn})$ dan variabel terikat atau variabel akibat $(Y)$ dari data yang ada.

3. Hitung nilai total dari masing-masing variabel $(\Sigma X 1, \Sigma X 2, \Sigma X n \Sigma Y, \Sigma X 1 Y, \Sigma X 2 Y, \Sigma X n Y$, $\Sigma X 1 X 2, \Sigma X n X n, \Sigma X 1^{2}, \Sigma X 2^{2}$ dan $\left.\Sigma X n^{2}\right)$.

4. Menurut Setiawan (2015: 2) "Untuk menghitung nilai dari a, b1, b2,.., bn digunakan Metode Kuadrat Terkecil (Least Square Method) yang membentuk beberapa persamaan normal".

Maka dari nilai total masing-masing variabel akan dimasukkan kedalam persamaan linier seperti berikut ini :

Persamaan 1

Persamaan 2

$$
\Sigma Y=a n+b 1 \Sigma X 1+b 2 \Sigma X 2+\ldots \ldots .+b n \Sigma X n
$$

$$
\Sigma \mathrm{X} 1 \mathrm{Y}=\mathrm{a} \Sigma \mathrm{X} 1+\mathrm{b} 1 \Sigma \mathrm{X} 1^{2}+\mathrm{b} 2 \Sigma \mathrm{X} 1 \mathrm{X} 2+\ldots . .+\mathrm{bn} \Sigma \mathrm{X} 1 \mathrm{Xn}
$$

\section{Persamaan 3}

$$
\begin{aligned}
\Sigma X 2 Y & =a \Sigma X 2+b 1 \Sigma X 1 X 2+b 2 \Sigma X 2^{2}+\ldots . .+b n \Sigma X 2 X n \\
\text { Persamaan } n & \\
\Sigma X n Y & =a \Sigma X n+b 1 \Sigma X n X 2 n+b 2 \Sigma X n^{2}+\ldots . .+b n \Sigma X n X n
\end{aligned}
$$

5. Lakukan perhitungan dengan menggunakan metode eliminasi dari persamaan-persamaan linier yang dibentuk agar didapat nilai a, b1, b2 dan bn.

6. Menerapkan rumus dari persamaan regresi linier berganda dibawah ini :

$$
\begin{array}{lll} 
& \mathbf{Y}=\mathbf{a}+\mathbf{b} \mathbf{\mathbf { X } 1} \mathbf{+} \mathbf{b} \mathbf{2} \mathbf{X} \mathbf{2}+\ldots+\mathbf{b} \mathbf{\mathbf { X n }} \\
\text { Dimana: } & \mathrm{Y} & =\text { Variabel terikat } \\
\mathrm{X} 1, \mathrm{X} 2, \mathrm{X} & =\text { Variabel bebas } \\
\mathrm{a} & =\text { Konstanta } \\
\mathrm{b} 1, \mathrm{~b} 2, \mathrm{bn} & =\text { Koefisien Regresi }
\end{array}
$$

Dengan menerapkan rumus persamaan regresi linier yang didapat maka hasil $Y$ atau variabel prediksi akan diketahui.

\subsection{Pertumbuhan Jumlah Penderita Human Immunodeficiency Virus (HIV)}

Menurut Aryani dan Pramitasari [7] "Obat yang dapat menyembuhkan HIV belum ditemukan hingga saat ini dan jumlah penderita HIV dari tahun ke tahun terus mengalami peningkatan secara global".

Berdasarkan Profil Kesehatan Provinsi Sumatera Utara tahun 2017, tahun 2017 sendiri tercatat 2.211 kasus HIV/AIDS dengan penambahan sekitar 185 kasus setiap bulannya.

Diantara faktror yang dapat mempengaruhi nilai pertumbuhan jumlah penderita HIV diantaranya adalah jumlah penderita HIV yang dirujuk ke PDP (Pelatihan Perawatan, Dukungan dan Pengobatan), dimana menurut Anwar [8] "Untuk memperlambat perkembangan virus dan hidup normal lebih lama, penderita HIVIAIDS harus mematuhi terapi ARV." artinya terapi dilakukan ditempat yang telah disediakan yaitu PDP. Selain itu faktor lain yang mempengaruhi adalah jumlah kondom yang diberikan ke klien, sebagaimana yang dikemukakan dalam Muryani [9] 'Persentase faktor risiko HIV tertinggi adalah hubungan seks yang tidak aman baik secara heteroseksual, Isl dan lain-lain', dengan kata lain penggunaan kondom adalah bentuk pengamanan dalam hubungan seks.

\section{Metodologi}

Adapun beberapa metode yang digunakan dalam penelitian yaitu sebagai berikut : 
1. Pengumpulan Data, dilakukan melalui observasi, wawancara dan studi pustaka.

2. Analisis Masalah dan Kebutuhan, yaitu menganalisa data yang diperoleh dengan mengimplementasikan metode yang digunakan.

3. Perancangan sistem dan pemodelan, yaitu merancang dan memodelkan sistem dengan menggunakan UML. Menurut Isa dan Hartawan [10] "Unifed Modeling Language (UML) adalah sebuah notasi grafis yang membantu mendesain sistem, khususnya sistem yang dibangun dengan pemrograman berorientasi objek"

4. Pengkodean, yaitu membuat program dengan aplikasi pemrograman

5. Pengujian, yaitu menguji sistem untuk melihat kelebiahan dan kelemahannya.

\section{Hasil dan Diskusi}

\subsection{Analisis}

Dari data yang ada dilakukan analisa agar dapat diterapkan dengan menggunakan metode regresi linier berganda dengan menentukan terlebih dahulu variabel yang dibutuhkan, kemudian selanjutnya melakukan proses prediksi.

Algoritma dalam penyelesaian masalah ini adalah sebagai berikut:

1. Mempersiapkan data untuk memprediksi pertumbuhan jumlah penderita HIV, data diambil dari data yang sudah ada bersumber dari Dinas Kesehatan Provinsi Sumatera Utara dan telah dikelompokkan dalam kelas-kelas tertentu.

Tabel 1: Data Pertumbuhan Jumlah Penderita HIV Periode 2018

\begin{tabular}{|l|l|l|l|l|l|l|}
\hline No & Bulan & $\begin{array}{c}\text { Jumlah } \\
\text { Orang } \\
\text { yang dites } \\
\text { HIV }\end{array}$ & $\begin{array}{c}\text { Jumlah } \\
\text { Penderita HIV } \\
\text { Positif dirujuk } \\
\text { kePDP }\end{array}$ & $\begin{array}{c}\text { Jumlah } \\
\text { Penderita HIV } \\
\text { Positif dikaji } \\
\text { gejala TB }\end{array}$ & $\begin{array}{c}\text { Jumlah } \\
\text { Kondom yang } \\
\text { diberikan ke } \\
\text { klien }\end{array}$ & $\begin{array}{c}\text { Jumlah } \\
\text { Penderita } \\
\text { HIV } \\
\text { Positif }\end{array}$ \\
\hline 1 & Januari & 8860 & 97 & 79 & 3499 & 318 \\
\hline 2 & Februari & 11502 & 154 & 129 & 3935 & 212 \\
\hline 3 & Maret & 8975 & 126 & 118 & 2571 & 166 \\
\hline 4 & April & 9929 & 158 & 143 & 3026 & 186 \\
\hline 5 & Mei & 10012 & 134 & 112 & 1992 & 159 \\
\hline 6 & Juni & 6691 & 53 & 51 & 1272 & 175 \\
\hline 7 & Juli & 10026 & 139 & 128 & 1173 & 174 \\
\hline 8 & Agustus & 9483 & 169 & 135 & 2242 & 227 \\
\hline 9 & September & 9554 & 138 & 132 & 2432 & 205 \\
\hline 10 & Oktober & 8839 & 130 & 131 & 1806 & 253 \\
\hline 11 & November & 7507 & 122 & 113 & 1901 & 154 \\
\hline 12 & Desember & 10217 & 87 & 97 & 1482 & 120 \\
\hline
\end{tabular}

(Sumber : Dinas Kesehatan Provinsi Sumatera Utara)

2. Menentukan variabel bebas atau variabel sebab dan tidak bebas atau variabel akibat atau disebut juga variabel prediktor dari data yang telah didapatkan.Variabel-variabel yang digunakan adalah sebagai berikut:
a. Jumlah Orang yang dites HIV (X1)
b. Jumlah Penderita HIV Positif di rujuk ke PDP (X2)
c. Jumlah Penderita HIV Positif di kaji gejala TB (X3)
d. Jumlah Kondom yang diberikan ke klien (X4)
e. Variabel tidak bebas yaitu: Jumlah Penderita HIV Positif (Y)

J-SISKO TECH Vol. 3, No. 1, $2020: 137-147$ 
3. Menghitung nilai total dari masing-masing variabel yang berfungsi untuk membentuk persamaan linier agar memudahkan dalam mencari koefisien regresi.

Nilai total :

$\mathrm{X} 1=111,595 \mathrm{X} 3=1,368 \mathrm{Y}=2,349 \mathrm{X} 2 \mathrm{Y}=0,018788 \mathrm{X} 4 \mathrm{Y}=0,292754$

$\mathrm{X} 2=1,507 \mathrm{X} 4=27,331 \mathrm{X} 1 \mathrm{Y}=21,829501 \mathrm{X} 3 \mathrm{Y}=0,017402 \mathrm{X} 1 \mathrm{X} 2=0,915854$

$\mathrm{X} 1 \mathrm{X} 3=0,848291 \mathrm{X} 2 \mathrm{X} 3=0,18078 \mathrm{X} 3 \mathrm{X} 4=3,177099 \times 2^{\wedge} 2=0,201009 \times 4^{\wedge} 2=$

70,46887

$\mathrm{X} 1 \mathrm{X} 4=259,4686 \mathrm{X} 2 \mathrm{X} 4=3,554988 \mathrm{X} 1^{\wedge} 2=1055,538 \mathrm{X} 3^{\wedge} 2=0,163772$

4. Membuat Persamaan Linier

Persamaan linier dibentuk dimaksudkan untuk diterapkan dalam metode eliminasi agar mempermudah mencari nilai $a, b_{1}, b_{2}, b_{3}, b_{4}$.

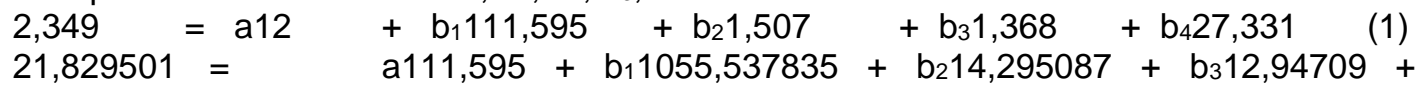

b4259,468592 (2)

$0,297336=a 1,507+b_{1} 14,295087+b_{2} 0,201009+b_{3} 0,18078+b_{4} 3,554988$ (3)

$0,267551=a 1,368+b_{1} 12,94709+b_{2} 0,18078+b_{3} 0,163772+b_{4} 3,177099$

$5,61496=a 27,331+b_{1} 259,468592+b_{2} 3,554988+b_{3} 3,177099+b_{4} 70,468869$

Perhitungan dengan Metode Eliminasi

Dari persamaan linier yang telah dibentuk proses eliminasi pun mulai dilakukan. Yang pertama dilakukan adalah proses eliminasi antara persamaan

(1) dan persamaan (2) seperti berikut ini:

$2,349=a 12+b_{1} 111,595+b_{2} 1,507+b_{3} 1,368+b_{4} 27,331$ (1) $\times 111,595$

$21,829501=a 111,595+b_{1} 1055,537835+b_{2} 14,295087+b_{3} 12,94709+b_{4} 259,468592(2)$ $\times 12$

$262,136655=a 1339,14+b_{1} 12453,44403+b_{2} 168,173665+b_{3} 152,66196+$
$b_{43050,002945}$
$261,954012=a_{1339,14}+b_{1} 12666,45402+b_{2} 171,541044+b_{3} 155,36508+$
$b_{43113,623104}$

$0,182643=0+b_{1}-213,009995+b_{2}-3,367379+b_{3}-2,70312+b_{4}-63,620159$ (6)

Kemudian dilakukan proses eliminasi antara persamaan (1) dan persamaan (3) seperti berikut ini:

$2,349=a 12+b_{1} 111,595+b_{2} 1,507+b_{3} 1,368+b_{42} 2,331(1) \times 1,507$

$0,297336=a 1,507+b_{1} 14,295087+b_{2} 0,201009+b_{3} 0,18078+b_{4} 3,554988(3) \times 12$

$3,539943=a 18,084+b_{1} 168,173665+b_{2} 2,271049+b_{3} 2,061576+b_{4} 41,187817$

$3,568032=a 18,084+b_{1} 171,541044+b_{2} 2,412108+b_{3} 2,16936+b_{4} 42,659856$

$-0,028089=0+b_{1}-3,367379+b_{2}-0,141059+b_{3}-0,107784+b_{4}-1,472039$ (7)

Kemudian dilakukan proses eliminasi antara persamaan (1) dan persamaan (4) seperti berikut ini:

$2,349=a 12+b_{1} 111,595+b_{2} 1,507+b_{3} 1,368+b_{4} 27,331(1) \times 1,368$

$0,267551=a 1,368+b_{1} 12,94709+b_{2} 0,18078+b_{3} 0,163772+b_{4} 3,177099(4) \times 12$

$3,213432=a 16,416+b_{1} 152,66196+b_{2} 2,061576+b_{3} 1,871424+b_{4} 37,388808$

$3,210612=a 16,416+b_{1} 155,36508+b_{2} 2,16936+b_{3} 1,965264+b_{4} 38,125188$

$0,00282=0+b_{1}-2,70312+b_{2}-0,107784+b_{3}-0,09384+b_{4}-0,73638$ 
Kemudian dilakukan proses eliminasi antara persamaan (1) dan persamaan (5) seperti berikut ini:

$$
\begin{array}{lcrr}
2,349 & =a 12+b_{1} 111,595 & +b_{2} 1,507+b_{3} 1,368+b_{4} 27,331 & (1) x \\
27,331 &
\end{array}
$$

$64,200519=a 327,972+b_{1} 3050,002945+b_{2} 41,187817+b_{3} 37,388808+b_{4} 746,983561$ $67,37952=a 327,972+b_{1} 3113,623104+b_{2} 42,659856+b_{3} 38,125188+b_{4} 845,626428$

$-3,179001=0+b_{1}-63,620159+b_{2}-1,472039+b_{3}-0,73638+b_{4}-98,642867$

Kemudian setelah proses eliminasi antara persamaan (1) hingga persamaan (5) dilakukan, maka terbentuk persamaan baru seperti berikut ini:

$0,182643=b_{1}-213,009995+b_{2}-3,367379+b_{3}-2,70312+b_{4}-63,620159$

$-0,028089=b_{1}-3,367379+b_{2}-0,141059+b_{3}-0,107784+b_{4}-1,472039$

$0,00282=b_{1}-2,70312+b_{2}-0,107784+b_{3}-0,09384+b_{4}-0,73638$

$-3,179001=b_{1}-63,620159+b_{2}-1,472039+b_{3}-0,73638+b_{4}-98,642867$

Kemudian dilakukan proses eliminasi antara persamaan (6) dan persamaan (7) seperti berikut ini:

$0,182643=b_{1}-213,009995+b_{2}-3,367379+b_{3}-2,70312+b_{4}-63,620159(6) \times-3,367379$

$-0,028089=b_{2}-3,367379+b_{2}-0,141059+b_{3}-0,107784+b_{4}-1,472039$ (7) $x-$

213,009995

$-0,615028203=b_{1} 717,285384+b_{2} 11,33924133+b_{3} 9,102429522+b_{4} 214,2331874$

$5,98323775=b_{1} 717,285384+b_{2} 30,04697688+b_{3} 22,9590693+b_{4} 313,55902$

$-6,598265952=0+b_{2}-18,70773556+b_{3}-13,85663978+b_{4}-99,32583264(10)$

Kemudian dilakukan proses eliminasi antara persamaan (6) dan persamaan (8) seperti berikut ini:

$0,182643=b_{1}-213,009995+b_{2}-3,367379+b_{3}-2,70312+b_{4}-63,620159(6) \times-2,70312$

$0,00282=b_{1}-2,70312+b_{2}-0,107784+b_{3}-0,09384+b_{4}-0,73638$ (8) $x-213,009995$

$-0,493705946=b_{1} 575,7915777+b_{2} 9,102429522+b_{3} 7,306857734+b_{4} 171,9729242$

$-0,600688186=b_{1} 575,7915777+b_{2} 22,9590693+b_{3} 19,98885793+b_{4} 156,8563001$

$0,10698224=0+b_{2}-13,85663978+b_{3}-12,6820002+b_{4} 15,11662408(11)$

Kemudian dilakukan proses eliminasi antara persamaan (6) dan persamaan (9)

$0,182643=b_{1}-213,009995+b_{2}-3,367379+b_{3}-2,70312+b_{4}-63,620159$ (6) $\times-63,620159$

$-3,179001=b_{1}-63,620159+b_{2}-1,472039+b_{3}-0,73638+b_{4}-98,642867$ (9) $x-213,009995$

$-11,6197767=b_{1} 13551,72975+b_{2} 214,2331874+b_{3} 171,9729242+b_{4} 4047,524631$

$677,1589871=b_{1} 13551,72975+b_{2} 313,55902+b_{3} 156,8563001+b_{4} 21011,91661$

$-688,7787638=0+b_{2}-99,32583264+b_{3} 15,11662408+b_{4}-16964,39198$ (12)

Kemudian setelah proses eliminasi antara persamaan (6) hingga persamaan (9) dilakukan, maka terbentuk persamaan baru seperti berikut ini:

$-6,598265952=b_{2}-18,70773556+b_{3}-13,85663978+b_{4}-99,32583264$

$0,10698224=b_{2}-13,85663978+b_{3}-12,6820002+b_{4} 15,11662408$

$-688,7787638=b_{2}-99,32583264+b_{3} 15,11662408+b_{4}-16964,39198$

J-SISKO TECH Vol. 3, No. 1, $2020: 137-147$ 
Kemudian dilakukan proses eliminasi antara persamaan (10) dan persamaan (11) seperti berikut ini:

$-6,598265952=b_{2}-18,70773556+b_{3}-13,85663978+b_{4}-99,32583264$

$0,10698224=b_{2}-13,85663978+b_{3}-12,6820002+b_{4} 15,11662408$

$91,42979446=b_{2} 259,2263527+b_{3} 192,006466+b_{4} 1376,322284$

$-2,00139545=b_{2} 259,2263527+b_{3} 237,251506+b_{4}-282,7978057$

$93,43118991=0+b_{3}-45,24504003+b_{4} 1659,120089$

Kemudian dilakukan proses eliminasi antara persamaan (10) dan persamaan (12) seperti berikut ini:

$-6,598265952=b_{2}-18,70773556+b_{3}-13,85663978+b_{4}-99,32583264$ $-688,7787638=b_{2}-99,32583264+b_{3} 15,11662408+b_{4}-16964,39198$

$655,3782597=b_{2} 1858,161411+b_{3} 1376,322284+b_{4} 9865,621029$

$12885,49097=b_{2} 1858,161411+b_{3}-282,7978057+b_{4} 317365,3589$

$-12230,11271=0+b_{3} 1659,120089+b_{4}-307499,7379$

Kemudian setelah proses eliminasi antara persamaan (10) hingga persamaan (12) dilakukan, maka terbentuk persamaan baru seperti berikut ini:

$93,43118991=b_{3}-45,24504003+b_{4} 1659,120089$

$-12230,11271=b_{3} 1659,120089+b_{4}-307499,7379$

Kemudian dilakukan proses eliminasi antara persamaan (13) dan persamaan (14) seperti berikut ini:

$93,43118991=b_{3}-45,24504003+b_{4} 1659,120089$

$-12230,11271=b_{3} 1659,120089+b_{4}-307499,7379$

(13) $\times 1659,120089$

(14) $x-45,24504003$

$155013,5642=b_{3}-75066,95485+b_{4} 2752679,471$

$553351,9391=b_{3}-75066,95485+b_{4} 13912837,95$

$-398338,375=0+b_{4}-11160158,48$

Dari persamaan 15 maka akan dicari nilai dari $b_{4}$.

$-398338,375=b_{4}-11160158,48$

$\mathrm{b}_{4} \quad=-398338,375 /-11160158,48$

$\mathrm{b}_{4} \quad=0,035692896$

Hasil b4 akan dimasukkan antara persamaan (13) atau (14) untuk mencari nilai $b_{3}$ Dalam hal ini digunakan persamaan (13) sehingga hasilnya seperti berikut ini:

$93,43118991=b_{3}-45,24504003+b_{4} 1659,120089$

$93,43118991=b_{3}-45,24504003+(0,035692896 * 1659,120089)$

$93,43118991=b_{3}-45,24504003+59,21880065$

$93,43118991-59,21880065=b_{3}-45,24504003$

$34,21238926=b_{3}-45,24504003$

$\mathrm{b}_{3}$

$\mathrm{b}_{3}$

$=34,21238926 /-45,24504003$

$=-0,756157785$

Hasil $b_{4}$ dan $b_{3}$ akan dimasukkan antara persamaan (10) atau (11) untuk mencari nilai $b_{2}$.

Dalam hal ini digunakan persamaan (11) sehingga hasilnya seperti berikut ini:

$-6,598265952=b_{2}-18,70773556+b_{3}-13,85663978+b_{4}-99,32583264$

$-6,598265952=b_{2}-18,70773556+\left(-0,756157785^{*}-13,85663978\right)+\left(0,035692896^{*}-\right.$ $99,32583264)$

$-6,598265952=b_{2}-18,70773556+10,47780605+-3,545226606$

$-6,598265952=b_{2}-18,70773556+6,93257944$ 


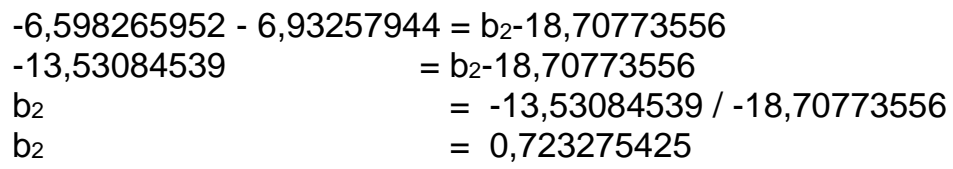

Hasil $b_{4}, b_{3}$, dan $b_{2}$ akan dimasukkan antara persamaan (6) atau (7) untuk mencari nilai $b_{1}$. Dalam hal ini digunakan persamaan (6) sehingga hasilnya seperti berikut ini:

$0,182643=b_{1}-213,009995+b_{2}-3,367379+b_{3}-2,70312+b_{4}-63,620159$

$0,182643=b_{1}-213,009995+\left(0,723275425^{*}-3,367379\right)+\left(-0,756157785^{*}-2,70312\right)+$ $\left(0,035692896^{*}-63,620159\right)$

$0,182643=b_{1}-213,009995+-2,435542479+2,043985232+-2,270787713$

$0,182643=b_{1}-213,009995+-2,662344959$

$0,182643+2,662344959=b_{1}-213,009995$

$2,844987959=b_{1}-213,009995$

$b_{1} \quad=2,844987959 /-213,009995$

$b_{1} \quad=-0,013356124$

Hasil $b_{4}, b_{3}, b_{2}$ dan $b_{1}$ akan dimasukkan antara persamaan (1) atau (2) untuk mencari nilai a. Dalam hal ini digunakan persamaan (1) sehingga hasilnya seperti berikut ini:

$2,349=a 12+b_{1} 111,595+b_{2} 1,507+b_{3} 1,368+b_{4} 27,331$

$2,349=\mathrm{a} 12+\left(-0,013356124^{\star} 111,595\right)+\left(0,723275425^{\star} 1,507\right)$ $+\left(-0,756157785^{*} 1,368\right)+\left(0,035692896^{*} 27,331\right)$

$2,349=\mathrm{a} 12+-1,490476686+1,089976066+-1,03442385+0,975522538$

$2,349=\mathrm{a} 12+-0,459401931$

$2,349+0,459401931=\mathrm{a} 12$

$2,808401931=\mathrm{a} 12$

$\mathrm{a}=2,808401931 / 12$

a $\quad=0,234033494$

Sehingga didapatkan nilai seperti berikut ini :

a $=0,234033494$

$b_{1}=-0,013356124$

$b_{2}=0,723275425$

$b_{3}=-0,756157785$

$\mathrm{b}_{4}=0,035692896$

6. Memasukkan nilai $a, b_{1}, b_{2}, b_{3}$ kedalam rumus persamaan regresi linier berganda.

Rumus persamaan regresi linier berganda yaitu :

$\mathrm{Y}=\mathrm{a}+\mathrm{b}_{1} \mathrm{X} 1+\mathrm{b}_{2} \mathrm{X} 2+\mathrm{b}_{3} \mathrm{X} 3+\mathrm{b}_{4} \mathrm{X} 4$

Maka persamaan yang didapat menjadi :

$\mathrm{Y}=0,234033494+-0,013356124 X 1+0,723275425 X 2+-0,756157785 X 3$ $+0,035692896 \times 4$

Maka untuk memprediksi pertumbuhan jumlah penderita HIV untuk bulan berikutnya yaitu bulan januari berdasarkan data yang sebelumnya adalah seperti berikut ini :

Diketahui :

a. Jumlah Orang yang dites HIV = 10,217 (X1)

b. Jumlah Penderita HIV positif dirujuk ke PDP $=0,087(\mathrm{X} 2)$

c. Jumlah Penderita HIV positif di kaji gejala TB $=0,097(\mathrm{X} 3)$

d. Jumlah Kondom yang diberikan ke klien $\quad=1,482(X 4)$

Maka pertumbuhan jumlah penderita HIV atau $Y$ adalah sebanyak :

$\mathrm{Y}=0,234033494+-0,013356124 \mathrm{X} 1+0,723275425 \mathrm{X} 2$ $+-0,756157785 \times 3+0,035692896 \times 4$

$\mathrm{Y}=0,234033494+\left(-0,013356124^{\star} 10,217\right)+\left(0,723275425^{\star} 0,087\right)$ $+\left(-0,756157785^{\star} 0,097\right)+\left(0,035692896^{*} 1,482\right)$

$\mathrm{Y}=0,234033494+(-0,136459521)+0,062924962+0,073347305+0,052896872$ 
$Y=0,140048501$

Karena data telah disederhanakan dengan membagi 1000, sekarang akan dikalikan dengan 1000 untuk mendapatkan hasil yang akurat.

$Y=1400485014$

$\mathrm{Y}=140$ (Pembulatan)

Maka diprediksikan bahwa pertumbuhan jumlah penderita HIV untuk bulan berikutnya adalah sebanyak 140 Penderita.

\subsection{Hasil}

Form Data merupakan tampilan yang memuat informasi tentang data pertumbuhan jumlah penderita HIV . Tampilan form Data dapat dilihat pada gambar di bawah ini

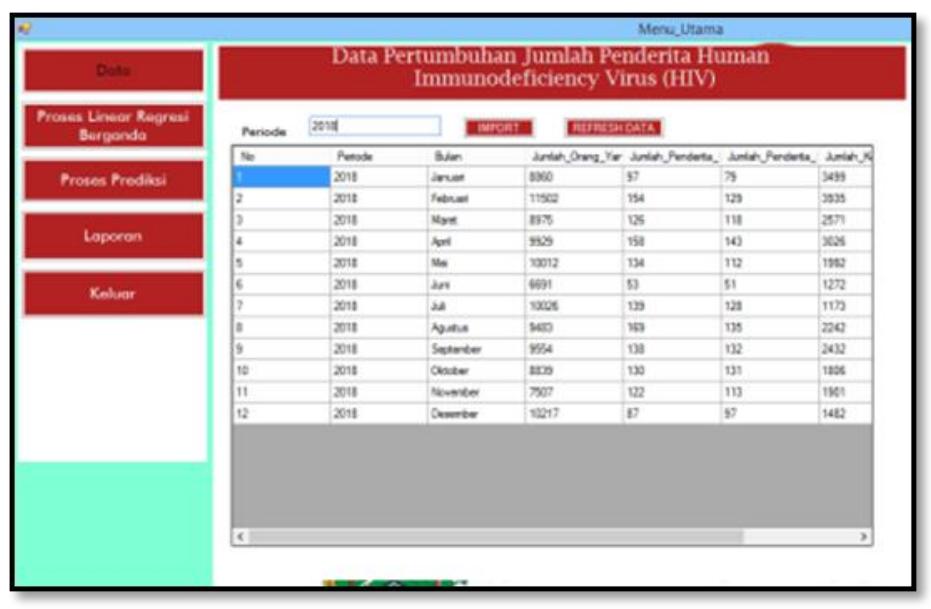

Gambar 1 Tampilan Form Data

Form Proses Perhitungan Regresi Linier Berganda merupakan halaman yang menampilkan bagaimana proses dari algoritma regresi linier berganda dengan tampilan berikut ini.

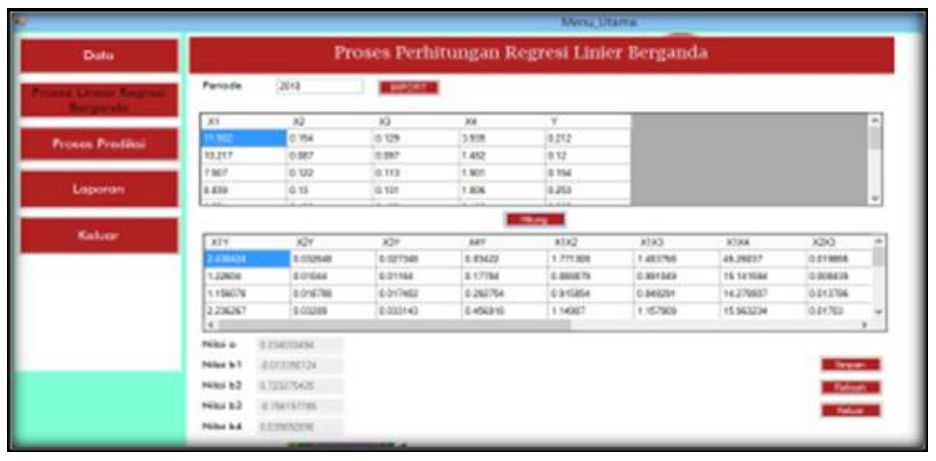

Gambar 2 Tampilan Form Proses Perhitungan Regresi Linier Berganda 
Form Proses Prediksi merupakan form yang digunakan untuk memprediksi pertumbuhan jumlah penderita HIV untuk bulan berikutnya. Tampilan form Prediksi dapat dilihat pada gambar di bawah ini.

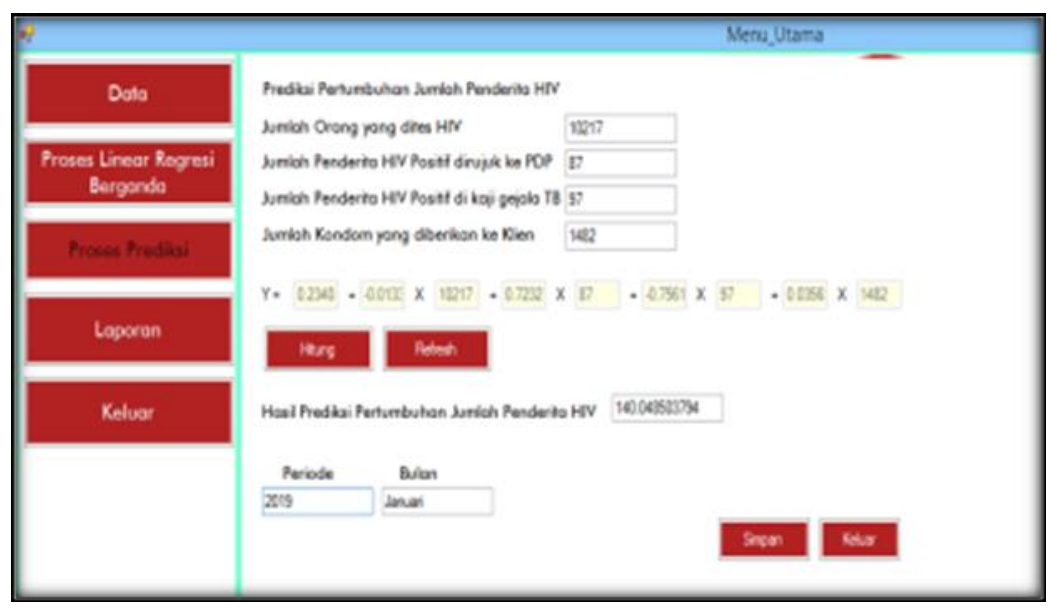

Gambar 3 Tampilan Form Proses Prediksi

Form Laporan merupakan tampilan yang berisi Laporan yang sudah diselesaikan dengan menggunakan metode Regresi Linier Berganda.Tampilan laporan dapat dilihat pada gambar dibawah ini.

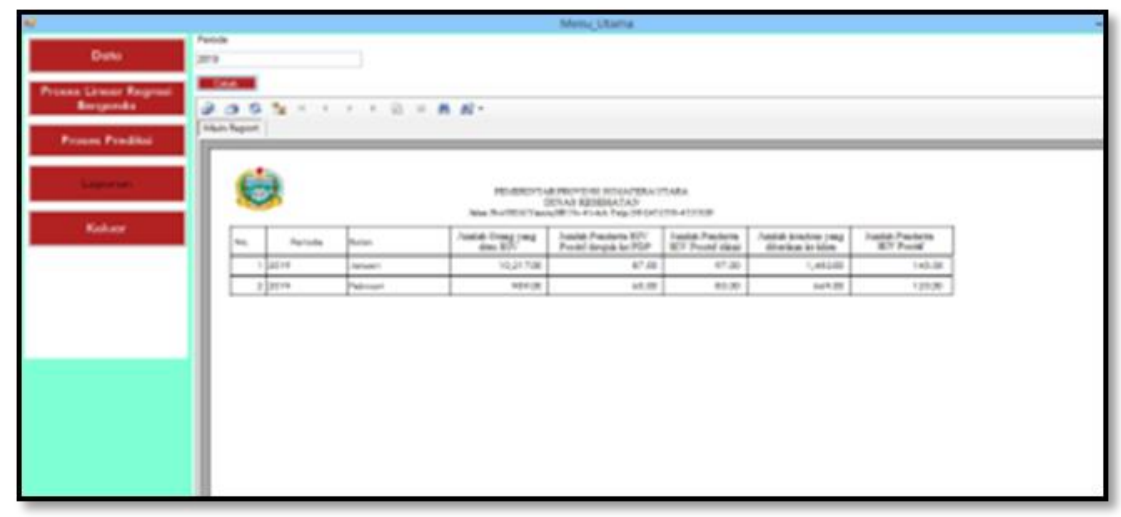

Gambar 4 Tampilan Form Laporan

\section{Kesimpulan}

Berdasarkan dari penelitian yang telah dilaksanakan maka dapat diambil kesimpulan sebagai berikut:

1. Dalam menerapkan data mining untuk memprediksi pertumbuhan jumlah penderita HIV membutuhkan sejumlah data kemudian data dikelompokkan kedalam kelas-kelas tertentu seperti no, jumlah orang yang dites HIV, jumlah penderita HIV positif dirujuk ke PDP, jumlah penderita HIV positif dikaji gejala TB, jumlah kondom yang diberikan ke klien, jumlah penderita HIV positif. 
2. Perancangan suatu sistem yang dapat menerapkan metode Multiple Linier Regression dalam memprediksi pertumbuhan jumlah penderita HIV menggunakan pemodelan Flowchart dan Unified Modelling Language (UML) yang meliputi use case diagram, activity diagram dan class diagram.

3. Sistem yang dirancang dapat mengimport data pertumbuhan jumlah penderita HIV kemudian tersimpan didatabase, sistem juga dapat melakukan proses perhitungan dengan mengggunakan metode regresi linier berganda mulai dari proses menginisialisasi variabel hingga mencari nilai koefisien regresi kemudian sistem juga dapat memprediksi pertumbuhan jumlah penderita HIV untuk bulan berikutnya.

\section{Referensi}

[1] Y. Marlinda and Azinar, "Perilaku Pencegahan Penularan HIVIAIDS," J. Heal. Educ., pp. 192-200, 2017.

[2] D. SU, "Profil Dinas Kesehatan Provinsi Sumatera Utara 2017," vol. 91, 2017.

[3] Y. Yasmiati, W. Wahyudi, and A. Susilo, "Pengembangan Aplikasi Data Mining Dengan Algoritma C4.5 Dan Apriori Di Fakultas Teknologi Informatika Universitas Respati Indonesia," J. Teknol., vol. Volume 9 N, pp. 31-41, 2017.

[4] Zulham and Nasyuha, "Penerapan Data Mining Untuk Pengelompokan Wahana Terfavorit Pada CV. Hairos Indah Menggunakan Metode K- Means," SAINTIKOM, vol. 17, p. 93, 2018.

[5] E. Prasetyo, Data Mining - Konsep dan Aplikasi Menggunakan MATLAB. Gresik: ANDI, 2012.

[6] A. Amrin, "Data Mining Dengan Regresi Linier Berganda Untuk Peramalan Tingkat Inflasi," J. Techno Nusa Mandiri, vol. xiii, pp. 74-79, 2016.

[7] L. Aryani and R. Pramitasari, "Perkembangan Kasus HIV di Kota Semarang: Tinjauan Karakteristik dan Aspek Lingkungan," J. Kesehat. Masy. Indones., vol. 13, pp. 7-12, 2018.

[8] Y. Anwar and S. Nugroho, "No TitleKarakteristik Sosiodemografi, Klinis, dan Pola Terapi Antiretroviral Pasien HIV/AIDS di Rspi Prof. DR. Sulianti Saroso Periode Januari - Juni 2016 Characteristic," Pharm. J. Farm. Indones. (Pharmaceutical J. Indones., vol. Vol.15, pp. 314-320, 2017.

[9] Muryani and S. Sarumpaet, "Pengaruh Jumlah Pasangan Seks Terhadap Infeksi HIV Pada Pecandu Narkoba di Klinik Voluntary Counseling Testing (VCT) Rsu Kabanjahe Kabupaten Karo Tahun 2017.," J. Med. Respati, vol. Vol. 13, pp. 19-25, 2018.

[10] Isa and Hartawan, "Perancangan Aplikasi Koperasi Simpan Pinjam Berbasis Web," J. IIm. IImu Ekon., vol. Vol. 5 Edi, pp. 139-151, 2017. 